\title{
Case report on necrotizing fasciitis following episiotomy
}

\author{
Bhabani Pegu*, Jayalakshmi D., Avantika Gupta
}

Department of Obstetrics and Gynecology, JIPMER, Puducherry, India

Received: 31 January 2020

Accepted: 29 February 2020

\author{
*Correspondence: \\ Dr. Bhabani Pegu, \\ E-mail: bpeguamc@gmail.com
}

Copyright: (C) the author(s), publisher and licensee Medip Academy. This is an open-access article distributed under the terms of the Creative Commons Attribution Non-Commercial License, which permits unrestricted non-commercial use, distribution, and reproduction in any medium, provided the original work is properly cited.

\begin{abstract}
Necrotising fasciitis (NF) is an extremely rare but near fatal bacterial soft tissue infection, complicating the operative wounds. Here is a case report of Necrotising fasciitis in episiotomy wound in low socioeconomic, poorly nourished and anaemic women. A 39 years old, second gravida, delivered normally with medio-lateral episiotomy under local anaesthesia. On postnatal day four, patient developed high grade fever and on examination episiotomy was found to be unhealthy and gaped. She was started on broad spectrum antibiotics empirically but the cellulitis rapidly progressed to vulva, then to the bilateral thighs and extended till knees. Bilateral lower limb Doppler ultrasonography was done to rule out deep vein thrombosis which showed no abnormality. USG abdomen revealed huge pus collection in the lower abdomen. Under anaesthesia, surgical exploration was done, pus was drained followed by wound debridement and pus sent for culture and sensitivity. Pus and blood culture showed growth of Klebsiella pneumoniae, so started on appropriate antibiotics. Patient started recovering, when the wound was healthy, secondary suturing of episiotomy wound done. She was discharged on post-natal day 27 after full recovery. Early diagnosis and aggressive timely management are the corner stone to avoid morbidity and mortality of NF.
\end{abstract}

Keywords: Episiotomy, Morbidity, Necrotising fasciitis

\section{INTRODUCTION}

Necrotising fasciitis (NF) is a very rare and lifethreatening subcutaneous tissue infection. It is characterized by wide spread fascial necrosis with infarction and separation of subcutaneous tissue and overlying skin. The affected area may be erythematous, swollen, shiny warm to touch, painful and tender. It is usually accompanied by systemic toxic manifestations like decreased consciousness, multi organ failure and septic shock. ${ }^{1}$ It often occurs following a trauma, and rarely after a surgical procedure. ${ }^{2}$ Causative organisms can be beta haemolytic Group A Streptococcus, Staphylococcus aureus, Klebsiella pneumonia, Clostridium species, Prevotella species etc. ${ }^{3}$ Risk factors are diabetes mellitus, malnutrition, chronic illness and immunocompromised patients. In last decade, Necrotising fasciitis has also been reported in postpartum period. ${ }^{4,5}$

\section{CASE REPORT}

A 39 years old second gravida delivered normally with medio-lateral episiotomy under local anesthesia in a tertiary care hospital. She was an uncomplicated second gravida, with iron deficiency anaemia $(\mathrm{Hb}-8.8 \mathrm{~g} / \mathrm{dl})$ due to poor nourishment. Patient was not discharged for baby sake. On postnatal day four, she developed high grade fever and on examination, there was episiotomy wound gape with slough covering it, which was associated with cellulitis of vulva extending up to both knees. She had pain at symphysis pubis, aggravated on change of posture or movement of lower limbs. Wound swab, high vaginal swab and blood sample sent for culture and sensitivity and started her on broad spectrum antibiotics. Except tachycardia, all other vitals were stable. Her laboratory investigations were $\mathrm{Hb} 7.3 \mathrm{~g} / \mathrm{dl}$, TLC $22,000 / \mu \mathrm{L}$, total protein level $3 \mathrm{~g} / \mathrm{dl}$, serum albumin level $1.8 \mathrm{~g} / \mathrm{dl}$ with elevated liver enzymes. Renal function test and serum 
electrolytes were normal. Deep vein thrombosis was ruled out by lower limb Doppler ultrasonography and started on injection enoxaparin according to the weight of the patient as the patient was not ambulatory. Pelvic x-ray showed diastasis of symphysis pubis. It progressed very rapidly and involved lower abdomen. USG abdomen showed $8.2 \times 3.1 \mathrm{~cm}$ septate collection in the intramuscular plane, suggestive of abscess (Figure 1).

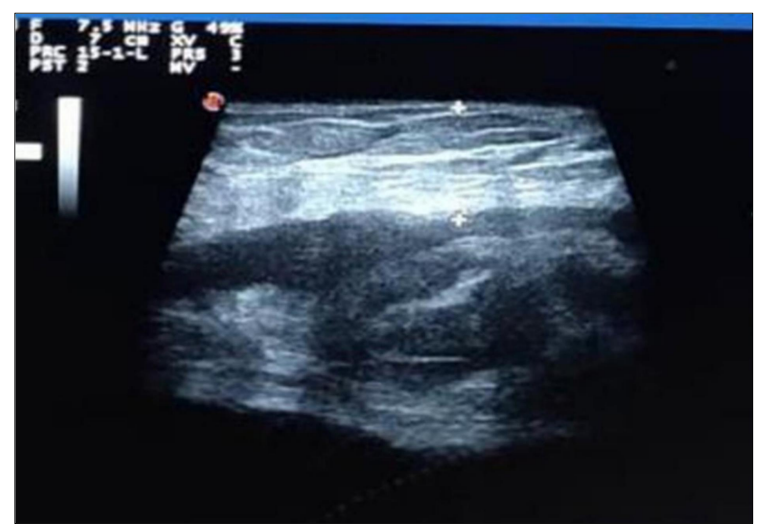

Figure 1: Pus collection in the intramuscular plane in lower abdomen.

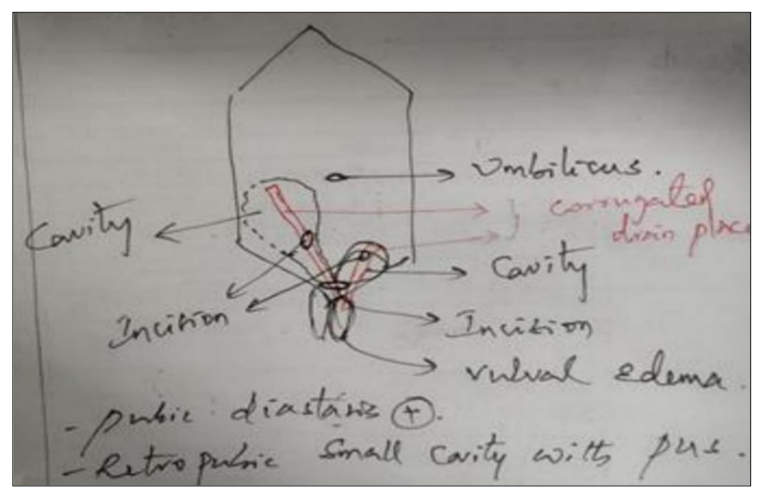

Figure 2: Different sites of incisions for pus drainage.

On postnatal day six, incision and drainage done, in association with surgeon. Three incisions, each of size 3 $\mathrm{cm}$ were made, two oblique para median and one midline over the lower abdomen (Figure 2). Around $700 \mathrm{ml}$ of pus was drained and subcutaneous drained was placed. Episiotomy wound debridement done in same setting. Tissue culture showed Klebsiella pneumoniae and she was started on appropriate antibiotics based on culture and sensitivity report. Orthopedics' opinion taken for pelvic diastasis, advised for pelvic binder and bed rest. High protein diet and other supportive care was given. She was transfused with one-unit packed cell in view of anaemia. Patient started recovering gradually. All abnormal laboratory parameters got corrected. Secondary suturing of episiotomy wound was done after healthy granulation tissue had formed. Patient was discharged on post-natal day 27 after full recovery.

\section{DISCUSSION}

In the $5^{\text {th }}$ century $\mathrm{BC}$ Hippocrates first described Necrotizing fasciitis as a complication of "erysipelas" and that the necrotizing fasciitis involving genital area as the most dangerous one. ${ }^{6}$ In the last century, mortality rate due to it was reported to be between $6 \%$ to $76 \%$. Various predisposing factors are described for the development of necrotizing fasciitis such as rheumatoid arthritis, SLE, diabetes, post renal transplantation, injection drug abusers, obesity, malnutrition, anaemia, immunocompromised patients or on immunosuppressive therapy. ${ }^{8,9}$ Post-operative infections accounts for $20 \%$, and it usually follows trivial trauma. In this case, anaemia, low serum protein, poor nourishment, and improper hygiene were found to be predisposing factors. $\mathrm{NF}$ in post-partum patients is a challenge both from diagnostic and management perspectives.

Early diagnosis and timely intervention are the key to reduce morbidity and mortality rates in NF. The clues for early recognition include pain out of proportion to the examination findings, rapid progression, systemic toxic symptoms and other abnormal laboratory findings. ${ }^{10,11}$ It is challenging in early stage to distinguish NF from other soft tissue infection due to non- specific findings. In a study of 22 patients with NF, 59\% were found to have only erythematous and tender skin lesions on day 0 , and in other study, signs like crepitus and frank necrosis, which are more suggestive of NF were found in less than $5 \%$ of patients on day 0 and $68 \%$ developed by day $4 .{ }^{12}$

Systemic toxicity such as fever, hemodynamic instability and multi-organ failure are not reliable diagnostic clues in early stage of disease but these are often stressed in describing NF. ${ }^{8}$ A retrospective study conducted by Wong et al reported that $47.2 \%$ of NF patients especially the immunocompromised ones, lack signs of fever and only $4.5 \%$ had multi-organ failure at admission. In this case, signs like high grade temperature, tachycardia, anaemia, elevated TLC and CRP and altered liver enzymes were there.

A study by Henry $M$ et al, found that delayed diagnosis and treatment will lead to poor outcome. ${ }^{7}$ Similarly, Faris et al reported that even with aggressive surgical debridement by hyperbaric oxygen, mortality was reported due to extensive disease and delay in diagnosis whereas Jiao L et al, and Robin et al, reported successful management of NF. ${ }^{13-15}$

\section{CONCLUSION}

To conclude, a physician must consider necrotising fasciitis in a patient with obstetrics operative procedure having high grade fever and any local signs of infection in puerperal period. Early diagnosis and aggressive management are the corner stone in reducing morbidity and mortality of NF. 
Funding: No funding sources Conflict of interest: None declared

Ethical approval: Not required

\section{REFERENCES}

1. Green RJ, Dafoe DC, Raffin TA. Necrotizing fasciitis. Chest. 1996;110(1):219-29.

2. Fallahzadeh H, Altenbernd E, Mays ET. Necrotizing fasciitis. Am Surg. 1974;40:352-4.

3. Brook I, Frazier EH. Clinical and microbiological features of necrotizing fasciitis. J Clin Microbiol. 1995;33(9):2382-7.

4. Golde S, Ledger WJ. Necrotizing fasciitis in postpartum patients. A report of four cases. Obstet Gynecol. 1977;50(6):670-3.

5. Ammari NN, Hasweh YG, Hassan AA, Karyoute S. Post-partum necrotizing fasciitis. Case report. BJOG: Inter J Obstet Gynaecol. 1986;93(1):82-3.

6. Descamps V, Aitken J, Lee MG. Hippocrates on necrotising fasciitis. The Lancet. 1994;344(8921):556.

7. McHenry CR, Piotrowski JJ, Petrinic D, Malangoni MA. Determinants of mortality for necrotizing softtissue infections. Ann Surg. 1995;221(5):558-65.

8. Sarani B, Strong M, Pascual J, Schwab CW. Necrotizing fasciitis: current concepts and review of the literature. J Am Coll Surg. 2009;208(2)279-88.

9. Park SY, Moon SY, Son JS, Lee MS. Fatal necrotizing fasciitis due to Streptococcus pneumoniae: a case report. J Korean Med Sci. 2011;26(1):131-4.
10. Majeski J, Majeski E. Necrotizing fasciitis: improved survival with early recognition by tissue biopsy and aggressive surgical treatment. Southern Med J. 1997;90(11):1065-8.

11. Wong CH, Chang HC, Pasupathy S, Khin LW, Tan JL, Low CO. Necrotizing fasciitis: clinical presentation, microbiology, and determinants of mortality. J Bone Joint Surg Am. 2003;85(8):145460.

12. Wang YS, Wong CH, Tay YK. Staging of necrotizing fasciitis based on the evolving cutaneous features. Inter J Dermatol. 2007;46(10):1036-41.

13. Almarzouqi F, Grieb G, Klink C, Bauerschlag D, Fuchs PC, Alharbi Z, et al. Fatal necrotizing fasciitis following episiotomy. Case Rep Surg. 2015;2015:562810.

14. Jiao L, Chagla Z, Kaki RM, Gohla G, Smieja M. Case report of necrotizing fasciitis associated with streptococcus pneumoniae. Can J Infect Dis Med Microbiol. 2016;2016:6872739.

15. Medhi R, Rai S, Das A, Ahmed M, Das B. Necrotizing fasciitis - a rare complication following common obstetric operative procedures: report of two cases. Int J Womens Health. 2015;7:357-60.

Cite this article as: Pegu B, Jayalakshmi D, Gupta A. Case report on necrotizing fasciitis following episiotomy. Int J Reprod Contracept Obstet Gynecol 2020;9:1732-4. 